Analysis

\title{
Did transition bring cleaner air? Effects of ownership, territorial and technology policy on air pollution
}

\author{
Camilla Jensen $^{\mathrm{a}, *}$, Andrea Mina ${ }^{\mathrm{b}, \mathrm{c}}$ \\ ${ }^{\text {a }}$ Dept. of Social Sciences and Business, Roskilde University, Denmark \\ ${ }^{\mathrm{b}}$ Institute of Economics, Scuola Superiore Sant'Anna, Pisa, Italy \\ ${ }^{\mathrm{c}}$ Centre for Business Research, Cambridge Judge Business School, University of Cambridge, Cambridge, UK
}

\section{A R T I C L E I N F O}

\section{Keywords:}

Foreign direct investment

Air pollution

Territorial policy

Technology policy

Green technologies

Policy mix

\begin{abstract}
A B S T R A C T
The paper investigates trends in air pollution in Poland during transition to a market economy. By analysing how the EU, national and regional development policy mix affects environmental outcomes we show the importance of context in terms of assessing the contribution to air pollution of different stakeholders such as foreign investors. The results show that while state owned firms pollute more, new domestic firms make a positive contribution to reducing emitted particulate matter and foreign owned subsidiaries on average have an increasing or neutral impact on air pollution. However, territorial policy becomes in Poland the focal point for understanding these changes as there are large differences for areas that are subject to this policy. When accounting for the combinations in these policies results suggest that zone governance has been very effective in reducing emissions of particulate matter. Zones combine ownership changes with technological changes associated with restructuring of enterprises and FDI along with EU subsidies associated with technology policies such as adoption of more green technologies in general. Both policy factors (e.g. using FDI to restructure former SOEs within the zones and using zones also as a policy tool to distribute structural funds) aid in reducing emissions, while to the extent we can compare them (due to differential measuring scales) we conclude that technology policy through structural funds has been by far the most effective policy tool towards curbing high emissions levels in Poland.
\end{abstract}

\section{Introduction}

One of the great expectations to the transition to capitalism in Eastern Europe was its side effects on the natural environment: in many countries there had been little technological change and the burden of production on the environment became clear during the 1980s (Brown et al., 2000). However, in the transition process the environmental impact of foreign direct investment (FDI) has been called into question.

On the one hand, a free market approach could imply that the reduction of negative externalities follows naturally from the introduction of incentives to technical change spearheaded mostly from abroad through FDI (Domanski, 2003; Jensen, 2002). On the other hand, research on FDI in developing countries has pointed out that industrial activity with the strongest negative externality will target countries that adopt a more lenient approach to environmental legislation. This argument is known as 'the pollution haven hypothesis' (Bommer, 1999; Cole, 2004; Eskeland and Harrison, 2003; He, 2006). Overall, because of the several contrasting forces at play and the contemporaneous impact of different policies, the outcome of the development process may have somewhat uncertain outcomes on pollution levels (Jaffe et al., 1995; Taylor, 2004).

We address this complex question by focussing on the case of Poland. This offers an invaluable opportunity to explore the levers of sustainability during broad socio-technological transitions (Geels, 2002 , 2004). We are especially interested in the relative role of domestic and foreign firms, and in the effect of place-based regional development policy (the special economic zones policy that facilitated FDI and new business creation during the transition period) and the effects of technology policy on air pollution emissions. Recent literature on this topic has brought to the fore the interplay between institutional and technological changes that are often spelled out at the regional level (Costantini and Mazzanti, 2012; Leoncini et al., 2016). This calls for a comprehensive assessment of the set of policy instruments that shape relevant economic incentives (Flanagan et al., 2011; Bachtler and Turok, 2013), including different aspects of the policy mix for sustainable transitions (Rogge and Reichardt, 2016; Edmondson et al., 2018).

We therefore investigate with regional panel data at the county level

\footnotetext{
* Corresponding author.

E-mail addresses: camje@ruc.dk (C. Jensen), andrea.mina@santannapisa.it (A. Mina).
} 
- whether and how the territorial and technology policy mix contributed to curb particulate matter (PM) emissions. To foreshadow the most interesting findings, we find that foreign owned subsidiaries have had on average a 'positive' (increasing) or neutral impact on air pollution, but contributing relatively more to output than to emissions, thus improving the overall sustainability balance (defined as the ratio between pollution and value added, see Eskeland and Harrison, 2003). Both the introduction of special economic zones in combination with FDI and environmental technology policy aided by EU subsidies have had significant effects, but technology policy has been particularly effective in reducing PM emissions levels.

\section{What do we know about the 'pollution haven' hypothesis?}

The literature on the pollution haven hypothesis is quite varied in terms of types and scope of studies (Erdogan, 2014; Cole et al., 2017). As data availability is a major factor of overall study validity, and therefore also a key determinant of the confidence we can have in the findings and the potential biases involved, it is essential to take into account the level of analysis. We first cover studies based on firm-level data, we then review the literature on industry-level data and finally the works that use regional data. Overall there is relatively strong evidence that foreign investors tend to be among the absolute most polluting firms. That is, they pollute more than the average firm in the host economy. However, when we consider their contribution to value added and exports, the net contribution to making production more sustainable in the host country is still positive, because the ratio between pollution to value added is lower for foreign investors relative to local firms due both to their superior technologies (Lanjouw and Mody, 1996; Letchumanan and Kodama, 2000; Ang, 2009) and to type of activities in which they specialise (see also Cole and Elliott, 2003). This is also the kind of projected or expected behaviour we see in the literature on tradeable $\mathrm{CO}_{2}$ permits across countries with different environmental standards and industrial pasts (Andersson, 2012). The argument is here that it could be ethically defensible to move polluting activities abroad due to differences in existing technologies and practices across countries, whereby the global welfare effect is positive and both parties will gain from the trade in permits and goods due to technology transfer (De Lucia, 2010).

\subsection{Firm-level studies}

Since pollution is often a type of point emission or potentially associated with a direct source or polluter, the availability of firm-level data towards testing the pollution haven hypothesis can be important. Problems of firm-level studies may be the types of pollution it has been possible to observe with micro datasets and the fact that oftentimes firm-level studies rely on sampled rather than population data. In one of the few studies with access to such data, using consumption of energy as a proxy for pollution intensity for Cote d'Ivoire, Mexico, Morocco and Venezuela, Eskeland and Harrison (2003) find that while foreign owned subsidiaries are producing more and therefore also polluting more, FDI still promotes greener and more energy-efficient technologies and therefore make a positive net contribution to a more sustainable production in the host country. In two studies with firm-level data for multinationals across a large number of host countries, Dam and Scholtens $(2008,2012)$ reassess the pollution haven hypothesis and find that outcomes depend both on the standards or quality of institutions in the host country and the standards or CSR policies adopted by multinational firms. Hence, they conclude that the pollution haven hypothesis is driven by a combination of countries with poor standards and firms with poor standards. Dam and Scholtens (2008) also find that it is often the larger multinational firms that invest in extensive CSR programs and therefore contribute relatively less to fulfilling the hypothesis' prediction. Kheder and Zugravu (2012) confirm the pollution haven hypothesis for middle (emerging economies and CEE) but not low income (developing and CIS) countries with the location decisions of French firms. However, in this case there is no documentation of de facto polluting behaviour of French multinationals and results may be driven by third factors that are unrelated or only indirectly related (such as electricity cost, e.g. as in Panhans et al., 2016) with polluting behaviours. Manderson and Kneller (2012) explicitly account for firm heterogeneity by controlling for the empirical regularity that it is the most productive firms in each industry that have been found to establish subsidiaries abroad. Accounting for a combination of the pollution intensity (measured as environmental compliance cost) of each industry and the stringency of standards abroad (environmental policy implemented in the host country), Manderson and Kneller (2012) find no robust evidence for the pollution haven hypothesis at least in the aspect of establishing multinational subsidiaries abroad. With a similar approach Rezza (2013) shows that the strategic motivations of Norwegian multinationals matter in the interaction between volume and direction of FDI with local environmental standards. It is efficiency-seeking multinationals that are more likely to fulfil the pollution haven hypothesis, but again there is no de facto evidence of emissions in the individual host country. Naughton (2014) and Candau and Dienesch (2017) obtain very similar results with a more aggregate country-level and affiliate level dataset respectively. These studies provide useful but only partial evidence, as they are unable to resolve the problem without observation of de facto emissions.

\subsection{Industry-level studies}

Industry level studies have arguably been the most popular in investigating the pollution haven hypothesis. The perspective taken in these studies is quite distinctive even though it also shares similarities with firm-level studies when the environmental variable is nested at the industry level (Mulatu, 2017). Industries are often classified by the stringency of environmental legislation enforced in the home or host country from the perspective of investing companies. The main argument of these studies is that if foreign investment is more prevalent in industries with more stringent standards (in the perspective of the home country - but lax if oppositely seen from the perspective of the host country), it is indicative of evidence in favour of the pollution haven hypothesis. Wagner and Timmins (2009) report for Germany at the level of industries that the deterrent effect of environmental regulations have a large and significant effect on German FDI outflows. Elliott and Shimamoto (2008) find no evidence of the pollution haven for Japanese investments in 3 ASEAN countries. Few of the industry level studies, however, are concerned about the validity of the findings considering that other factors that have little to do with de facto pollution or emissions levels in the target country could be driving these investments (e.g. the need to cut cost and offshore parts of their production activities). This argument has increased in importance as the trend towards more disaggregated global value chains have started to prevail. Furthermore, some of the pollution may also be entirely outsourced to third party producers and hence not observable in the data series on foreign direct investments by industry (see also Cole et al., 2017). A number of more recent studies in the same tradition (and especially when combining regulatory trends with information about the enforcement of these laws - hence e.g. reporting more robust governance indicators), and now with better panel data techniques that can account better also for industry-level differences and focusing instead on the stringency or laxity of environmental legislation in developing countries, have reported a relatively large effect of lack of environmental standards on outbound FDI activity from countries such as the US (Kellenberg, 2009), the UK (Mulatu, 2017) and in some industries also for the Netherlands (Poelhekke and Van der Ploeg, 2015).

One approach which is interesting in this perspective (but focusing more on trade in global value chains than FDI per se) involves looking at the pollution intensity of exports from the host countries. Such studies have been conducted for a number of countries. In a study of the 
pollution-intensity of exports for Turkey, Akbostanci et al. (2007) report that exports increase with the pollution intensity. Hering and Poncet (2014) report similar findings for Chinese exports at the level of cities and for privately owned firms, but with declining exports in response to more stringent regulation. However, state owned firms in this study were not similarly responsive in adjusting the pollution-intensity of exports to new environmental regulations.

In another study, which takes the opposite perspective of imports into the EU during a period of intense improvements in environmental standards in the Union, Cave and Blomquist (2008) found some evidence that the EU increased imports of goods in industries classified as dirty and toxic. However, Costantini and Mazzanti (2012) demonstrate that environmental regulation and standards can also be important drivers of EU export competitiveness and indirectly lead to more sustainable outcomes in host countries via technology transfer or as standards embedded in new and improved technological solutions. Relatedly, Leiter et al. (2011) show with European industry-level data that more stringent environmental regulation can be a driver of investments.

\subsection{Regional-level studies}

Relatively few studies have used regional datasets. It is often the case that available regional datasets only provide coarse information and this in itself reduces the accuracy of any attempt to ascribe behaviour to particular actors in any given location. Among the few exceptions there are three studies of Chinese regions that are especially interesting. Using data extracted from monitoring stations across 112 Chinese cities, Cole et al. (2011) report that the impact of foreign owned firms vary greatly by pollutant, being largest and significant for petroleum-like matter and smallest and insignificant for the air pollutants of waste gas, $\mathrm{SO}_{2}$, soot and dust. He (2006) uses provincial level data and the FDI capital stock as a proxy for the presence of foreign owned firms, and finds that FDI has a small but weakly positive effect on $\mathrm{SO}_{2}$ emissions. This study concludes that investors tend to seek industries with lower pollution compliance cost in China (which in part also owes to weak mechanisms of enforcement at the regional level). Tang et al. (2016) investigate a similar question (again with provincial data) but focus on haze pollution, which is somewhat overlapping with other categories of air pollution such as $\mathrm{SO}_{2}$, particulate matter and pollution with $\mathrm{CO}_{2}{ }^{1}$ They report a positive and significant, although small, effect of FDI on air pollution (in the order of $0.02 \%$ in response to a 1\% increase in FDI). Tang et al. (2016) find in parallel to both He (2006) and Eskeland and Harrison (2003) that while FDI contributes to elevating the overall level of pollution, the sustainability balance is likely to be positive due to the greater impact of foreign technologies on GDP and growth relative to pollution. In our analysis we follow this line of enquiry on pollution measured at the source at a fine-grained (county) level of geographical aggregation.

Overall our literature review demonstrates that there is increasingly strong evidence for a pollution haven hypothesis, but also that there is a need especially in the transition context to adopt a dynamic or paneldata based approach to this question. Because while FDI may introduce an element of fulfilling the pollution haven hypothesis, a somewhat overlooked element in many strands of the literature is that FDI will also typically bring technological change which in some circumstances can help to countervail the negative aspects. Increasingly it is also important to take into account the impact that global value chains rather than FDI alone will have on the location of polluting activities, the role played by policies of place that could relate to pollution and how

\footnotetext{
${ }^{1}$ Hazes are in particular a problem when different types of air pollution combine with the hot and humid climates that we often find in Asia. This condition creates a special toxic air that it can be particularly dangerous to breathe.
}

factor intensity may be differently related with the pollution haven hypothesis across different types of global value chains in terms of the relative role of FDI and trade.

\section{The context}

Within the European landscape Poland is particularly interesting because it has in the past and continues at present to top statistics that record high air pollution, especially of particulate matter which is considered dangerous to human health. The second source of interest in the Polish case is its process of transition towards a market based economy and European Union membership. And yet, perhaps surprisingly, there has been relatively few studies of how the environmental transition happened and took place, despite the publication of some major reports documenting significant advancement in this area since the early 1990s (see e.g. OECD, 2012, 2015; EEA, 2016; PAGE, 2017).

Fig. 1 provides the background for historical levels of industrial air pollution in Poland over the course of its economic transition. Over a 20-year period significant advances have been achieved with a reduction in air pollution with respect to particulate matter, today standing at $<10 \%$ of the level of air pollution at the outset of the transition process. ${ }^{2}$ Poland is nevertheless the single most polluted country in the EU when it comes to air pollution, with levels of emitted particular matter above the target values set by the European Union and the World Health Organisation (WHO) (see EEA, 2016, Page 28 and WHO and UNAIDS, 2006, Krzyzanowski and Cohen, 2008).

What Fig. 1 also reveals is that while (industrial) air pollution overall has gone down with the transition, there has been a trend towards a more skewed distribution (as captured with the coefficient of variation across the different geographical areas) in air pollution towards particular localities, and especially across Poland's six major regions, with air pollution now most strongly concentrated in the South of the country. In part this trend can also be due to the Green Lung policy that was adopted already in 1989 where a large part of land in the North-East was becoming one of the largest European natural reserves with hardly any industrial activity at all (GUS, 2017). Location of and activities with industries have therefore not acquired less importance than in the past but they may be subject to new patterns (e.g. types of behaviour and regulatory concerns) relatively to the past because of the privatisation process.

Fig. 2 (Map 1) shows the distribution of air pollution by county (powiat) in 2014. The Map makes it possible to visualise the precise location of the polluting activities. Industrial air pollution nowadays is concentrated outside major cities and skewed towards industrialised areas such as Upper Silesia and around the cities of Katowice, Krakow, Poznan, Szeczin and Lodz. Whereas past studies (as reviewed in Section 2) have mostly relied on firm-level data and industrial patterns and general activities and emission levels associated with industries, we are able to document quite specifically, by using detailed micro-regional data collected at the source of emission, the direct impact of different groups of firms on air pollution. To the best of our knowledge, this is the first contribution of its kind in Europe.

\section{Data}

The data used in the study come from the Polish Local Databank published online by the Central Statistical Office in Warsaw (www.bdl. stat.gov.pl). We use the LAU1 level in EU nomenclature (equivalent to 'powiat' level in the Polish nomenclature or to 'county' level in the UK nomenclature). Hereafter the study refers to the geographical unit of

\footnotetext{
${ }^{2}$ A note of caution is important here: while the transition has led to a large decrease in air pollution, the level of pollution that existed in the past may not be a relevant yardstick up to which the actions of current actors should be measured as far as environmental standards are concerned.
} 


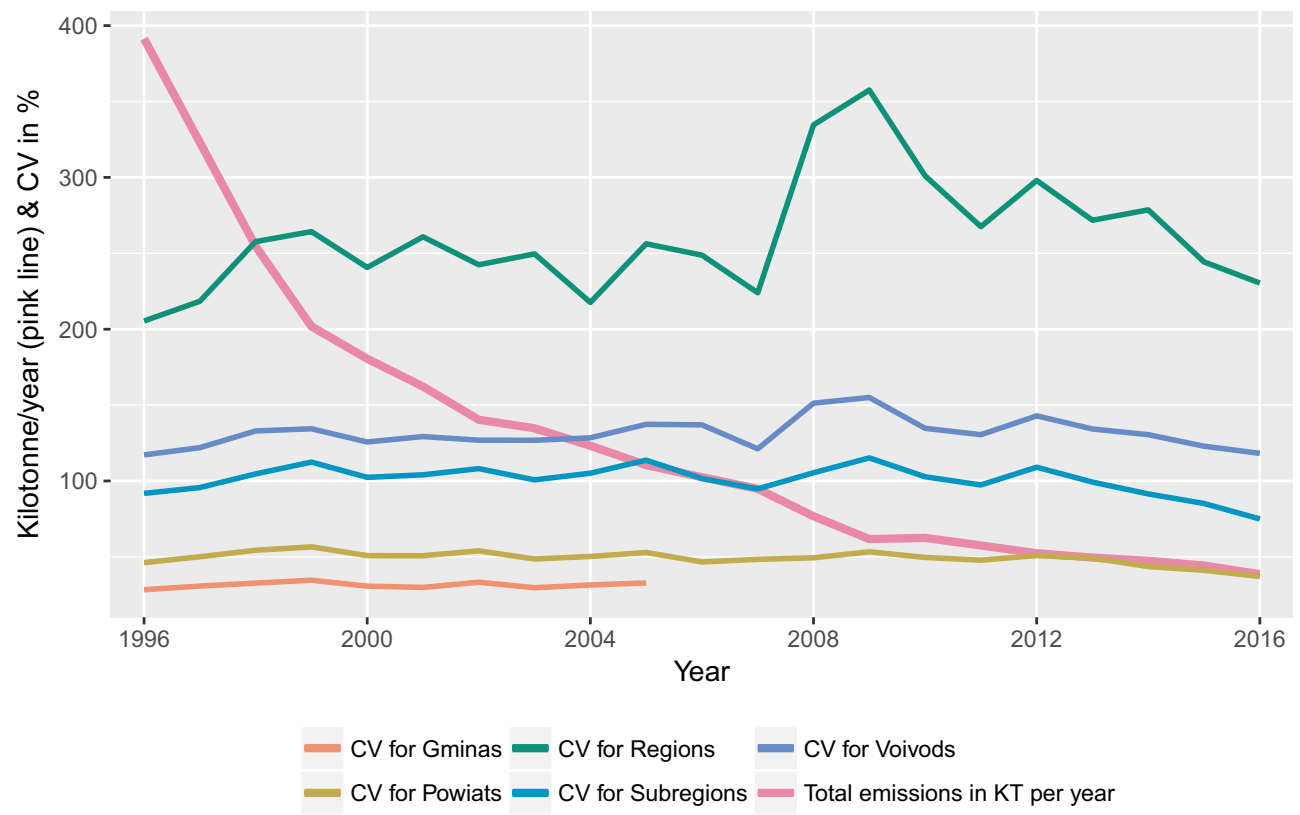

Fig. 1. PM emissions by industrial plants.

Source: Statistics Poland (2018): Local Databank, https://bdl.stat.gov.pl.

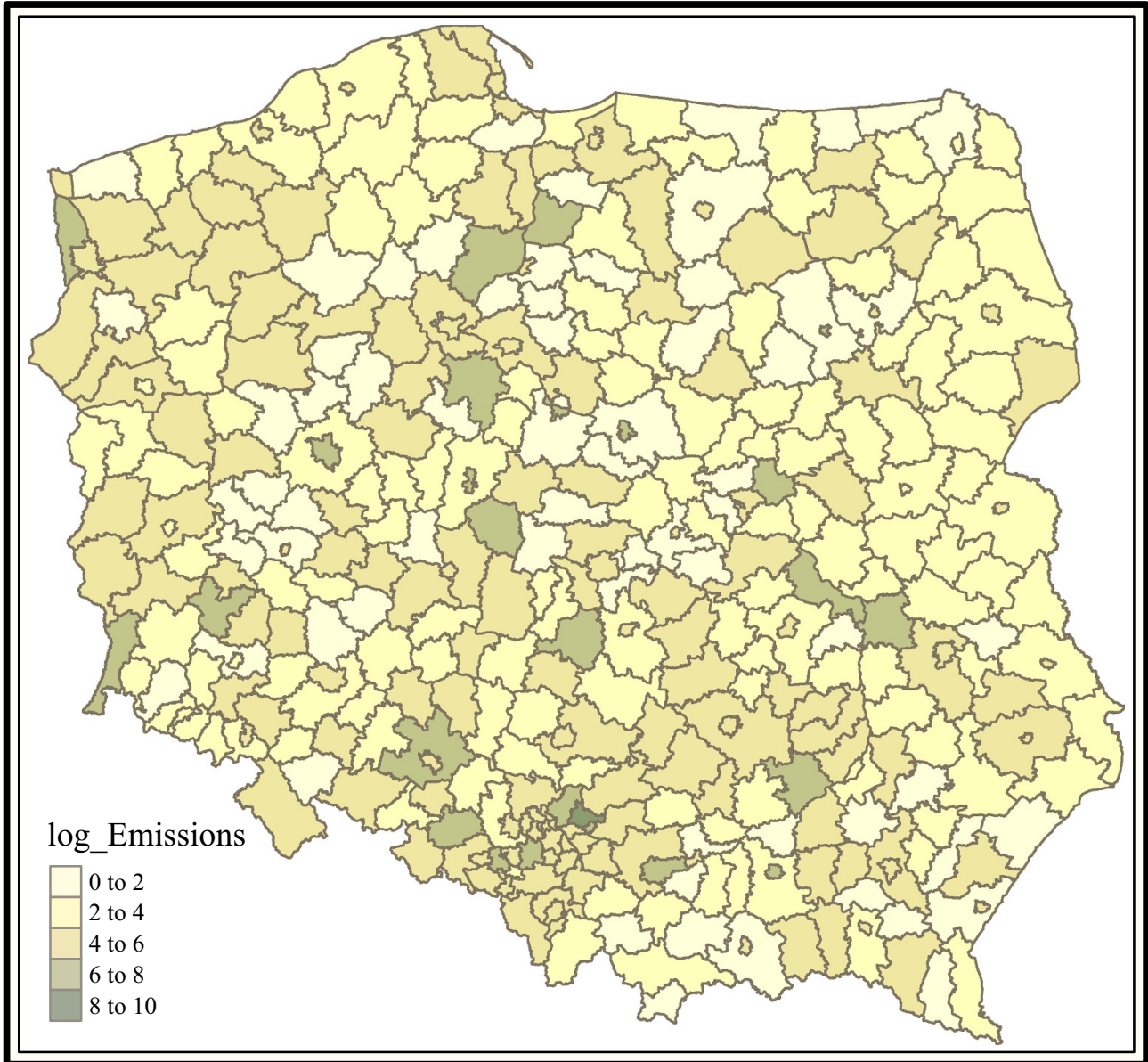

Fig. 2. Industrial PM emissions, 2014. 
analysis as powiat.

The main variables are emissions of air pollutants from plants that are especially noxious to air purity Emissions ${ }^{3}$ (quoted as particulates in tonnes per year), counts of firm populations by ownership All firms, Domestic owned firms, State owned firms and Foreign owned firms (no. of firms), and investments in green technology (total outlays on fixed assets serving environmental protection) Greentech investments (measured in thousand Polish zloty). The categories of Domestic owned and Foreign owned firms are obtained by using the variables on private entities and commercial (law) companies with foreign capital participation from the local databank and deducting from the former the latter to obtain a category of purely privately held domestic firms. Hence we include due to data availability any company with foreign capital that has been or is in the process of privatisation under the label FDI or foreign ownership. The ideal data would include firm counts or populations by entry mode (greenfield or acquisition) whereby we would have two ownership categories that would more perfectly map onto other comparable ownership categories (domestic private or state owned), but such data is not available from the local databank (see also Jensen, 2007). Important control variables are the share of agriculture Share of agriculture (calculated as the area of agricultural land to the total area of the powiat, both in $\mathrm{ha}^{4}$ ) and population Population (number of permanent residents). Public investment expenditure is included (in mio Polish zloty): this also controls for private investment because the two series are highly correlated (corr $>0.90$ ), and has the advantage of being available for a longer panel than private investment data. As instruments for investments in green technology, the series on corporate income tax Corporate taxes (in mio Polish zloty) and the series on EU subsidies EU subsidies (in mio Polish zloty) are used. Finally, area dummies are used (at the powiat level) when affected by the special economic zones policy which is time variant and has been collected directly from each zones administration (see also Jensen, 2018). This policy variable is referred to as Powiat with zones policy or simply as SEZ when used as an interaction term in conjunction with other variables.

Panel data summary statistics are shown with Appendix Table A1 for the study variables. The period of study is 1999-2014.

As the research confronts a multivariate problem, this section sets out the strategy we use to map and establish the relationship between pollution, location of economic activity in general and foreign direct investment in particular. Fig. 3 shows a plot of the emissions levels for Polish 'gminas' (communes in the UK or the LAU2 level in the EU nomenclature which is the lowest possible level of geographical detail in either classification system) in 1999 against the concentration of firm populations by ownership. From this simple plot it is observed that the location of Poland's state owned enterprises is one of the main sources behind air pollution with particulate matter. According to Fig. 3 foreign owned subsidiaries have not added much to these pre-existing pollution levels, but often located in the same areas where there is a high level of air pollution (partly due to the privatisation process whereby foreigners have bought and restructured former state owned enterprises), while new firms in general would tend to be associated with a reduction in the overall level of air pollution. (Partly because the new firms are located

\footnotetext{
${ }^{3}$ The following meta-data on the dependent variable is available from GUS (2016): "Data on emission from plants of significant nuisance to air quality come from annual CSO reports and pertain to organised emission (i.e. technological and heating devices, through emitters, chimneys, exhausts etc.) as well as non-organised emission (heaps, storage yards, in the course of reloading of loose and volatile materials, production halls etc.)"

${ }^{4}$ As the variable for agricultural land is only available before 2006 and after 2011, it is estimated for the interim period (2006-2011) as the average of its value in 2005 and 2012. It may still be time variant, but much less so, because the total area of the powiat may still change over the interim period. We also considered what happened to all specifications with and without this variable. However, including the Share of agriculture does not have any major influence on any of the results reported in the study.
}

outside areas with high pollution levels and also tend to cluster in less pollution intensive new-economy type of industries and in particular services have expanded with the economic transition (see e.g. Peng, 2001)). Hence due to intra- and inter-firm dynamics or ownership changes it is reasonable to expect that firm populations will contribute both to increases and decreases in emissions levels, where in practice the latter could take place when a new owner takes over an existing production apparatus and subsequently restructures it by changing (investing in new) products and/or production processes. Alternatively structural changes in emissions levels occur as old firms are closed down and new types of firms are opened in their place.

While Fig. 3 shows the prior level of air population plotted against firm populations at the outset of the period of investigation (1999), Fig. 4 shows in parallel hereto (but now only with data available at the powiat level which is somewhat coarser than the gmina level, e.g. we move from communes to whole counties) the change in the same two sets of variables over the period of study. Whereas the general change in firm populations is neutral or mildly positive (e.g. neutral due to ownership changes not having any influence on the overall number of firms and positive when there is a process of net entry as we would expect when going from a scenario with highly restricted entry to much fewer restrictions), while the number of state owned enterprises goes down and the number of foreign owned enterprises goes up during the period of study. Both are included in the category all firms (the series on domestic private owned firms has been suppressed in these comparisons). ${ }^{5}$ Whereas the scatter plot shows a consistent positive correlation between reduction in emissions and reduction in the category of state owned enterprises at the powiat level, the plot shows a dual tendency for foreign owned enterprises, where there is a neutral or slightly positive effect on emissions in one trend and a negative correlation between reduction in emissions and increases in the foreign owned category of firms in another trend. It is these trends that we now set out to document more precisely using multivariate panel data regression analysis.

\section{Econometric methodology}

Using the available longitudinal panel dataset that runs from 1999 until $2014(\mathrm{~T}=16)$ for the main variables, we investigate at the powiat or area level (of which there are on average 377 in Poland during the period of study) the development in emissions of particulate matter. The following base specification is adopted, where SOE, DOM and FOR represent the three ownership classes (state owned, domestic private held and foreign owned respectively) in our study, and $X$ is a set of control variables (Share of agriculture, Population and Public investment expenditure):

Emissions $_{i t}=\alpha_{i}+\beta_{1}{ }^{*} \operatorname{SOE}_{i t}+\beta_{2}{ }^{*} D O M_{i t}+\beta_{3}{ }^{*} \mathrm{FOR}_{i t}+\gamma_{k}{ }^{*} X_{i t}+\tau_{t}+\epsilon_{i t}$

Given area heterogeneity (as also captured in our dataset with the variable Area which reflects the actual physical size of each measured in ha), several econometric strategies are considered towards reducing area heterogeneity and aiding model interpretation. Standard options for parametric methods were considered including logarithmic transformation, application of manual weights or the estimation of weighted least squares. The latter method has several advantages if area heterogeneity turns out also to be a source of heteroscedasticity. For

\footnotetext{
${ }^{5}$ Note that here the firm populations are additive to the group of all firms, so that all firms are inclusive of both state owned and foreign owned enterprises. Hence the latter groups are to be read as 'deviations' from the group of all firms in Fig. 2a and b. In the subsequent regression analysis all firms have been divided out on domestic (private) owned, state owned and foreign owned respectively and each group therefore retain independent coefficient estimates in the statistical analysis.
} 


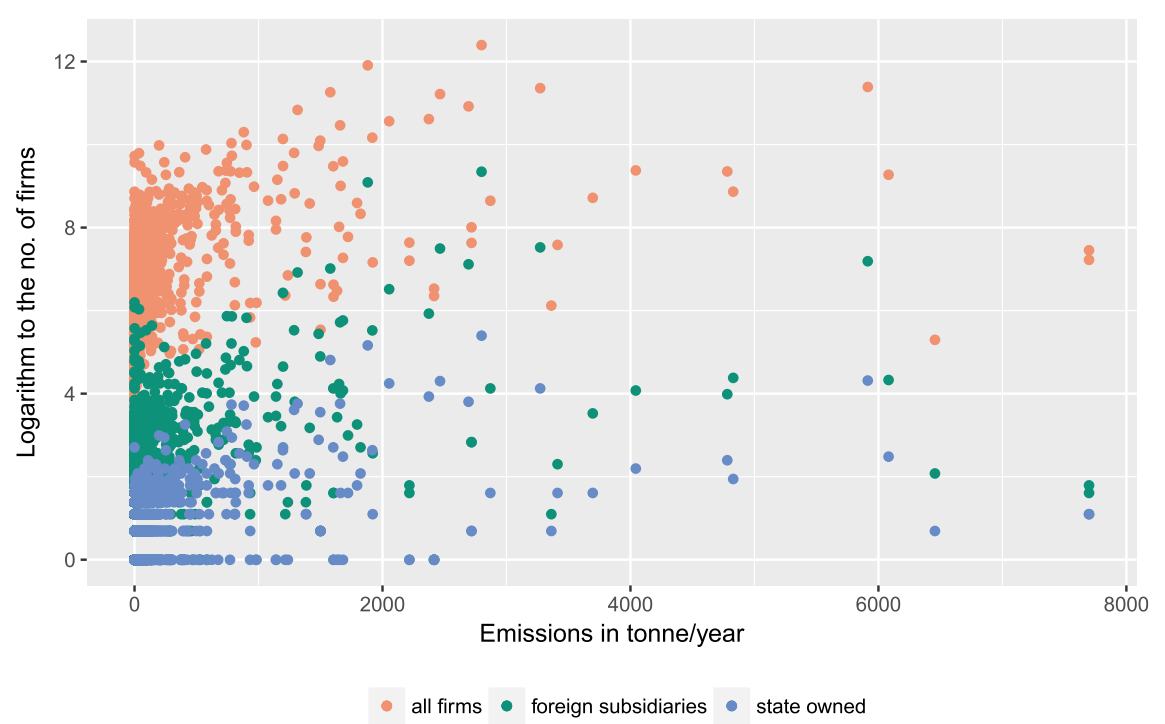

Fig. 3. Firm populations and emissions, 1999.

Source: Statistics Poland (2018): Local Databank, https://bdl.stat.gov.pl.

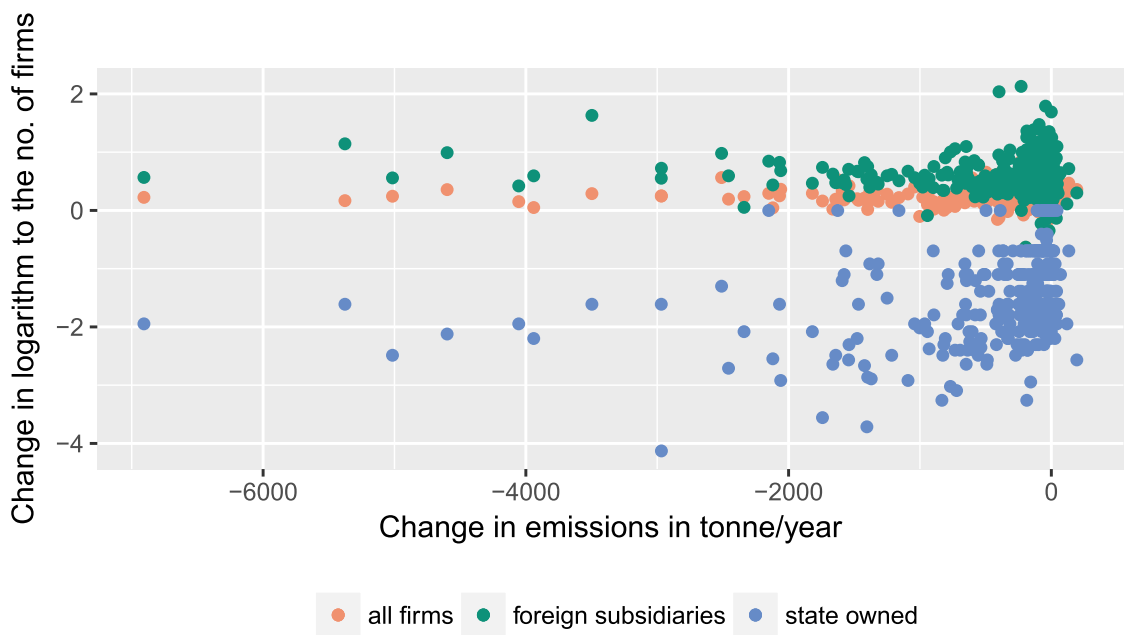

Fig. 4. Firm populations and emissions, change 1999-2014.

Source: Statistics Poland (2018): Local Databank, https://bdl.stat.gov.pl.

example, the problem of using logarithmic transformation for observations with the value 0 is avoided. Initially a manual weighting scheme was applied. However, manual weighting proved difficult towards interpretation of coefficient estimates which came out in varying sizes. Finally, and given that we found that the size of each area is a likely source of heteroscedasticity (e.g. our robust standard errors were less sensitive to the automatic weights which suggests that WLS takes care of a significant proportion of the likely problem of heteroscedasticity embedded in a panel dataset such as ours) we finally adopted automatic weights following this transformation:

$$
\begin{aligned}
\frac{\text { Emissions }_{i t}}{\sqrt{\text { Area }_{i t}}}= & \alpha_{i}+\beta_{1} \frac{\text { SOE }_{i t}}{\sqrt{\text { Area }_{i t}}}+\beta_{2} \frac{\text { DOM }_{i t}}{\sqrt{\text { Area }_{i t}}}+\beta_{3} \frac{\text { FOR }_{i t}}{\sqrt{\text { Area }_{i t}}}+\gamma_{k} \frac{X_{i t}}{\sqrt{\text { Area }_{i t}}} \\
& +\tau_{T}+\frac{\epsilon_{i t}}{\sqrt{\text { Area }_{i t}}}
\end{aligned}
$$

Compared to the original Eq. (1) we were thus able to tackle several model problems with one transformation and obtain more efficient and reliable estimators for the parameterised model.

\section{Regression analysis}

As a first step, we investigate model fit using the random effect and fixed effect panel data estimators for our base equation, the main objective being to understand the influence that foreign direct investment has had on emission levels of particulate matter over the period of study. As we will later see, a more accurate answer to this question also depends on the policy variables. We model as shown with Eqs. (1) and (2), emissions levels Emission for the $i$ 'th powiat at time $t$ as a function of firm populations by ownership types (domestic DOM, state owned SOE and foreign FOR) in a two-way fixed and random effects models, adopting Area size as weights (Eq. (2)) and by inclusion of the control variables: Share of agriculture, Population (rather than employment to avoid strong multicollinearity between control variables and our main explanatory variables) and Public investment expenditure.

Regression Table 1 reports results from regressing firm populations and our control variables on emissions of particulate matter at the powiat level over the period 1999-2014 with the fixed effect (within) and random effect estimators for panel data (operationalised with the package plm in $\mathrm{R}$ and streamlined regressions tables output owing to the Stargazer package delivered by Hlavac (2015)). The standard errors 
Table 1

Unweighted and weighted panel data estimators.

\begin{tabular}{|c|c|c|c|c|c|}
\hline & \multicolumn{5}{|c|}{ Dependent variable: } \\
\hline & \multicolumn{5}{|c|}{ Emissions } \\
\hline & \multicolumn{2}{|c|}{$\begin{array}{l}\text { panel } \\
\text { linear }\end{array}$} & \multicolumn{3}{|c|}{ felm } \\
\hline & $\begin{array}{l}\text { within+rob SE } \\
\text { (1) }\end{array}$ & $\begin{array}{c}\text { random+rob SE } \\
\text { (2) }\end{array}$ & $\begin{array}{c}\text { FOLS+rob SE } \\
\text { (3) }\end{array}$ & $\begin{array}{l}\text { FWLS } \\
\text { (4) }\end{array}$ & $\begin{array}{c}\text { FWLS+rob SE } \\
\text { (5) }\end{array}$ \\
\hline Domestic owned firms & $\begin{array}{l}-0.031 \\
(0.022)\end{array}$ & $\begin{array}{r}-0.044 * * \\
(0.019)\end{array}$ & $\begin{array}{l}-0.031 \\
(0.022)\end{array}$ & $\begin{array}{c}-0.032 * * * \\
(0.006)\end{array}$ & $\begin{array}{l}-0.032 * \\
(0.018)\end{array}$ \\
\hline State owned firms & $\begin{array}{l}13.468 * * * \\
(4.251)\end{array}$ & $\begin{array}{l}15.900 * * * \\
(5.007)\end{array}$ & $\begin{array}{l}13.468 * * * \\
(4.255)\end{array}$ & $\begin{array}{l}12.609 * * * \\
(1.711)\end{array}$ & $\begin{array}{l}12.609 * * * \\
(4.061)\end{array}$ \\
\hline Foreign owned firms & $\begin{array}{c}0.199 \\
(0.144)\end{array}$ & $\begin{array}{c}0.298 \\
(0.185)\end{array}$ & $\begin{array}{c}0.199 \\
(0.141)\end{array}$ & $\begin{array}{l}0.222 * * * \\
(0.045)\end{array}$ & $\begin{array}{l}0.222^{*} \\
(0.133)\end{array}$ \\
\hline Share of agriculture & $\begin{array}{c}1.104 \\
(3.395)\end{array}$ & $\begin{array}{l}-6.606 * * * \\
(1.977)\end{array}$ & $\begin{array}{c}1.104 \\
(4.399)\end{array}$ & $\begin{array}{l}0.990 \\
(2.397)\end{array}$ & $\begin{array}{c}0.990 \\
(5.219)\end{array}$ \\
\hline Population & $\begin{array}{r}0.007 * * * \\
(0.003)\end{array}$ & $\begin{array}{r}0.005 * * * \\
(0.001)\end{array}$ & $\begin{array}{r}0.007 * * * \\
(0.002)\end{array}$ & $\begin{array}{l}0.006 * * * \\
(0.001)\end{array}$ & $\begin{array}{l}0.006 * * \\
(0.002)\end{array}$ \\
\hline Public investment expenditure & $\begin{array}{r}-0.382 * * \\
(0.178)\end{array}$ & $\begin{array}{l}-0.749 \\
(0.624)\end{array}$ & $\begin{array}{r}-0.382 * * \\
(0.173)\end{array}$ & $\begin{array}{l}-0.516 * * * \\
(0.137)\end{array}$ & $\begin{array}{r}-0.516 * * \\
(0.216)\end{array}$ \\
\hline Observations & 6,047 & 6,047 & 6,047 & 6,047 & 6,047 \\
\hline $\mathrm{R} 2$ & 0.091 & 0.137 & 0.773 & 0.747 & 0.747 \\
\hline Adjusted R2 & 0.026 & 0.136 & 0.756 & 0.730 & 0.730 \\
\hline Residual Std. Error $(\mathrm{df}=5645)$ & & & 301.572 & $72,930.040$ & $72,930.040$ \\
\hline
\end{tabular}

Note:

reported in the first two columns of Table 1 are double-clustered robust and hence robust to errors clustering in both the powiat and time dimensions of the panel (see Cameron et al., 2011). A reasonable compromise and good alternative to reduce heterogeneity and avoid the problems involved when applying logarithms to zero inflated data is to apply the area sizes as weights using either a manual weighting scheme or automatic weighting with WLS instead of OLS as discussed under econometric methodology. ${ }^{6}$ The results shown in Table 1 are for the unweighted variables in the first three columns and for the weighted variables in the last two columns (automatic weights using the option 'weights' in the FELM package in R). Under the assumption that weights resolve problems of heteroscedasticity the interpretation of the coefficient estimates remain as per their original units.

The Hausman test was run to test the relative fit of the two panel data models with the data (e.g. Columns 1 and 2 in Regression Table 1). The Hausman test rejected the random effect model in favour of the fixed effect model with a $X^{2}=72.33$, rendering the random effect model inconsistent. ${ }^{7}$

In the third column of Table 1 we re-estimated the fixed effect model with the package felm in $\mathrm{R}$ which has the advantage that it reports the $\mathrm{r}^{2}$ for the full model (as opposed to only the projected model

\footnotetext{
${ }^{6}$ In a theoretical perspective there is nothing apriori to warrant that we need to weigh for area size from the viewpoint that there need not be a very high correlation between the density of economic and physical space owing to the phenomena of agglomeration economies. Perhaps rather the opposite which could be a good argument for weighing, e.g. powiats that are small in physical size but large in economic size will attain more influence in the weighted dataset. Small area size (due to economic agglomerations which are often also highly pollution intensive) is likely to lead to an underestimation of emissions and oppositely large area size (more prevalent for natural reserves or areas dense in agriculture and forestry but with low emissions levels in general) is likely to lead to an overestimation of emissions. Hence weighing with area size will reduce this source of heteroscedasticity in the dataset.

${ }^{7}$ This is also coherent with the more practical consideration that a fixed effect model is suitable when the data comprises all observations for the full population that the research seeks to describe or evaluate.
}

or the part of the model which is explained by the time variant independent variables when using the package plm). The coefficient estimate of interest in Regression Table 1 for the variable Foreign owned firms is large relative to that for Domestic owned firms, adopting weighted least squares all the ownership groups are significant. The preferred specification (Column 5 in Regression Table 1) demonstrates that the main factor behind industrial air pollution in Poland is the presence of firm populations inherited from the past (e.g. state owned firms - where one state owned firm per area on average increases emissions with $12.609 \mathrm{t}$ per year ${ }^{8}$ ), while foreign owned firms on average pollute more (e.g. one more foreign owned firm per area increases emissions with $0.222 \mathrm{t}$ of particulate matter per year), whereas domestic owned firms on average have a small but negative effect on air pollution.

Hence a generally higher domestic owned (e.g. Polish privately held) firm population in a certain area leads to on average less air pollution over time and foreign owned firms according to this result are not much different from the rest of the (new or privatised) Polish firms, but at the high end of pollution when compared to their private domestic held peers. Overall our results suggest that foreign owned firms have an impact in between domestic owned and state owned enterprises. This is not surprising as foreign owned firms comprise both new firms and former state owned enterprises undergoing restructuring.

Other potentially important explanatory factors of air pollution include areas with high population density (increases air pollution) and public investment expenditure (reduces air pollution). Here it is important to stress that air pollution from households is not included in

\footnotetext{
${ }^{8}$ This is a large effect given that the EU Ambient Air Quality Directive sets a target value of 25 micrograms per $\mathrm{m}^{3}$ per day when averaged out over the calendar year (see EEA, 2016, Page 27). For the Polish emissions context at the level of powiats it converts into 25 micrograms $\times 10,000$ (converting from $\mathrm{m} 3$ to ha) $\times 82,731$ (per average sized area or powiat in ha) $\times 365$ (days per year): $1,000,000,000,000$ (converting from micrograms into tonnes) $=7.549 \mathrm{t}$ per year per (average sized) area.
} 


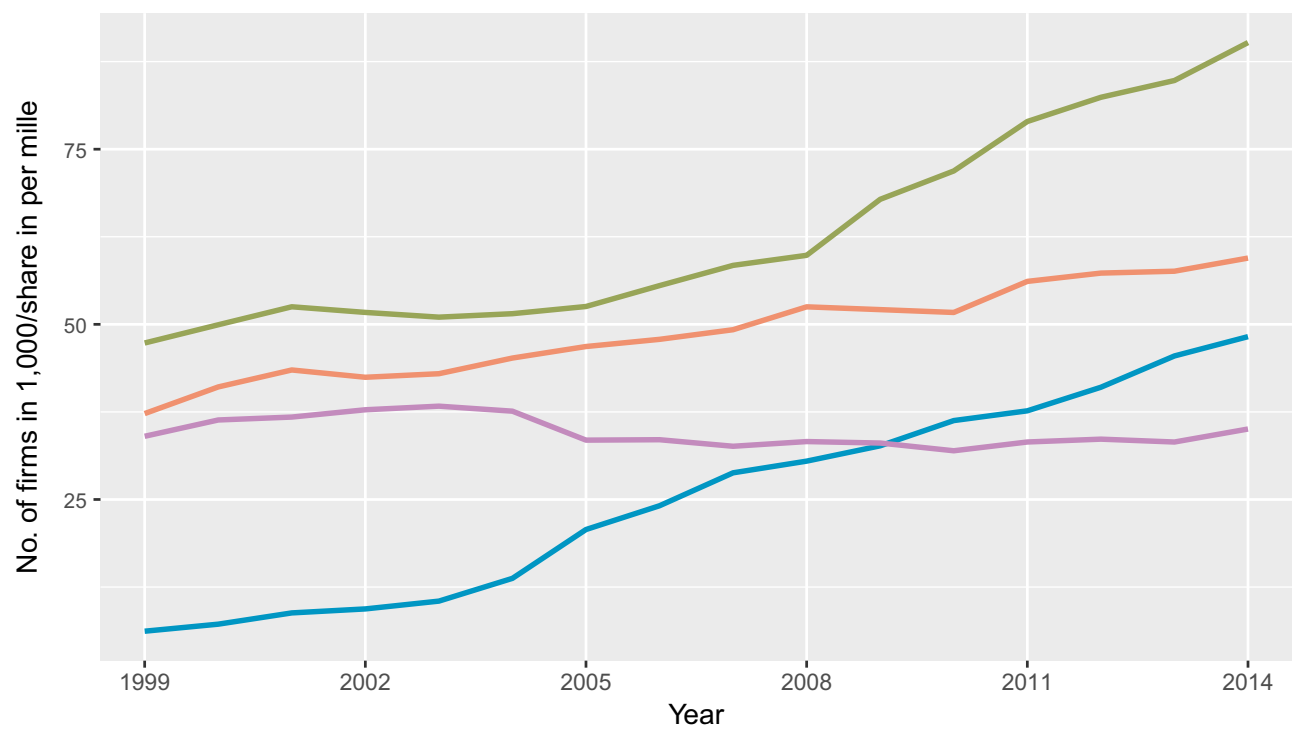

Fig. 5. Foreign firm populations in and out of the zones.

Source: Statistics Poland (2018): Local Databank, https://bdl.stat.gov.pl and Zone Management Companies.

the measurement of industrial emissions that our dependent variable captures, but population is strongly correlated with employment and thereby indirectly also captures the effect of the location of larger firms (which our firm variables are unable to do as they only reflect firm populations as counts) and the concentration of production in economic agglomerations. Only state owned enterprises stand out as the major polluters according to the results shown in Regression Table 1.

A robustness check on the results in Regression Table 1 is presented in Appendix 2. Here we use an alternative proxy for FDI (total capital invested in each powiat), which allows us to test the overall impact of FDI on the sustainability balance since this proxy, contrary to the number of firms, takes into account the relative size of firms. Even though the capital variable is only available for a short panel and only makes possible to discriminate between foreign and domestic ownership (but not public-private), it is still a useful complementary test. The results reported confirm the result from previous studies that per capital invested the net contribution of foreign capital to the sustainability balance is positive.

In the next section we split the sample into powiats with and without status of 'special economic zones'. Even though this is not an explicit mandate of the zones policy (see e.g. Gwosdz et al., 2008) it is important to investigate whether this policy has had any direct influence on the propensity of different firms to emit particulate matter and due to the importance it has assumed for employment patterns and the concentration of economic activity in the late industrialisation period in Poland after the economic transition in 1989 (see. e.g. Jensen, 2018). In the subsequent section on technology policy we focus then in addition on the effect of technology and structural policies including indirectly the adoption of green technology or of investments in more environmental friendly solutions, to test whether the incentives provided through the EU's structural funds have been used to make existing polluters and new potential polluters invest in such solutions and thereby whether these policies have worked as planned and helped to reduce industrial air pollution in Poland over the period of study.

\section{The role of territorial policy}

How did territorial policy influence the impact of FDI on air pollution? The main question is if the pollution intensity of foreign investors is affected by whether they are located within or in the vicinity of special economic zones. The zones are in this perspective important as they have been the main instrument of regional development policy during the Polish transition to capitalism. Initially the policy involved only 14 areas (and in size smaller than the gminas or communes) where the zone management companies now are located. Subsequent to EU accession at least $13 \%$ of land and up to half of all areas with any significant employment concentration outside Poland's capital cities (e.g. Warsaw, Gdansk and Poznan) have become involved in the land development scheme. Over time the zones have become the pivots for redirecting and governing the locational patterns of industrial activity in Poland. Due to the shift to a demand-led usage of the policy, whereby investors can effectively ask to have a new area enrolled under one of the existing administrations, zone administrations have come over time to replace traditional regional administrations in terms of being focal points for late industrialisation patterns in Poland. The zone administrations are there to deal with the many practical concerns of foreign investors (Dorożyński et al., 2017). In what must be seen as a traditionally non-federalist or unitary state structure, the zones administrations could be perceived as the direct arm of central government dealing with investors at the local administrative level. This could bypass the need or pressure for moving towards a federal or more decentralised regional governance system. The aim of the policy has always been to redirect (in part simply by maintaining employment structures) industrial activity and hence employment away from Poland's capital cities. Over time it can be argued that the focus has shifted more towards sustaining employment in areas that are hit hard by privatisation and the dismantling of state owned enterprises (Jensen, 2018). The zones policy thereby has become a focal point both for regional and ownership changes and with that also technological changes. Therefore we hypothesise that the impact of the policy is rather large in terms of aiding also the restructuring of state owned enterprises and thereby reduction in emissions because of ownership and technological changes.

While prior research suggest that the zones policy has been effective in meetings its main objective of securing employment for regional populations in Poland during the transition and EU accession period (see e.g. Cizkowicz et al., 2017, Jensen, 2018), there is less evidence especially after the policy has been rolled out that it has been effective in attracting FDI (for an early study see Ciezlik and Ryan, 2005). With the data available from the Local Databank we can observe that there 
Table 2

Emissions and the SEZ policy.

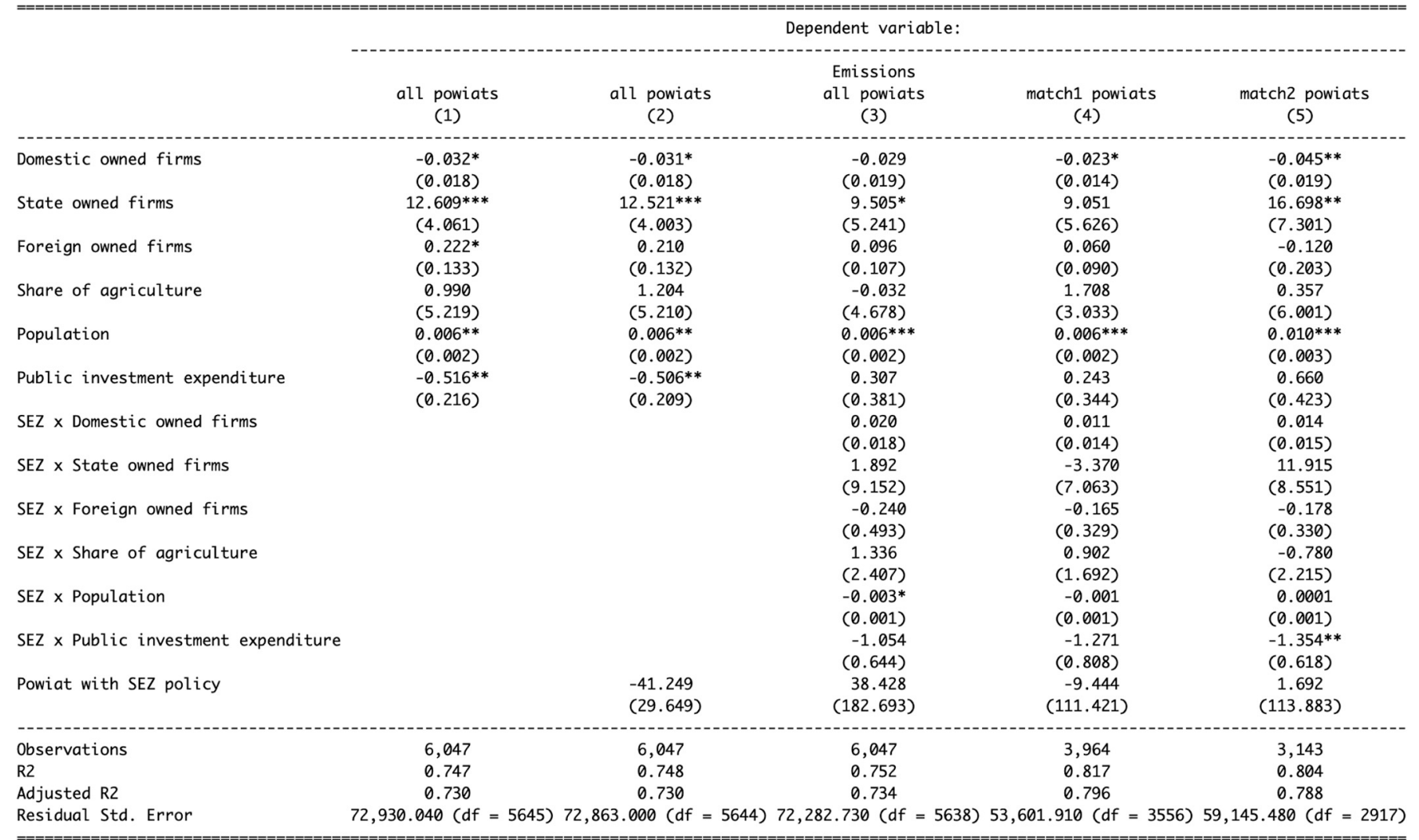

Note:

has been a tendency for the policy to become less focused on attracting foreign investors and has aimed over time more broadly to target any investor independent of national background.

Fig. 5 already showed that the proportion of foreign owned firms in the zones topped around the time of EU accession in 2004 in relative terms and levelled out, with most zones now having a mix of around $60-40 \%$ foreign-domestic investors (Adekoya, 2016). However, this exact mix cannot be observed from our data which is at the level of powiats, where the zones take up only a (often minor) part of the area of each powiat. At the powiat level the share of foreign subsidiaries is relatively modest at around 5\% in 2014 (notice the second axis in Fig. 5 is in per mille and not percentage). This is also not surprising as the policy over its lifetime has been mainstreamed and redirected from a supply- to demand-led model of land development, also considering that discriminatory tax incentives based on factors such as nationality would be in direct violation of EU law. One of the reasons why the policy has been so successful especially in some areas may be the incentives that the attraction of first generation FDI has given towards establishing a large second generation of smaller and locally owned suppliers. Hence foreign investors may have both a large direct and indirect impact on the evolution of emissions patterns and especially within the areas designated as special economic zones.

Regression Table 2 reports the results of running with outset in the base specification from Table 1 (Column 2 in Table 2), one specification where we include a simple dummy for powiats that have the zones policy (last row in Table 2). The impact of the zones policy on emissions is negative but insignificant.

Subsequently the full model (expanded with the SEZ dummy) is estimated and we also tried to include instead the centred explanatory variables for the interaction terms (not shown). However, neither of these specifications suggest that the difference in emissions is significantly different across areas with and without the zones policy. This may be due to the large heterogeneity that exists across areas with and without the policy (see also Jensen, 2018). Therefore, we adopted two different matching routines adjusted to the panel data dimensions. The results of the matching routines towards improving model fit via balancing the sample are shown in Columns 4 and 5 of Regression Table 2. The first matching routine (match1) applies nearest neighbour combined with Mahalanobis distance matching (without replacement), whereby we find the best match of treated areas up against non-treated areas in each year and we then re-stack the dataset into a panel. In the second matching routine (match 2, implemented with the $\mathrm{R}$ package MatchIt, in line with Stuart et al., 2011) we go back to 1999 to find the best match for any treated area over the horizon of the policy and then maintain this match consistently throughout the period of study. The main disadvantage of this method is that it is greedy in terms of observations lost to the matching routine (because of the gradual but also large invasion of the policy over time at the level of powiats). The first matching routine does not induce much change in results reported in Column 3 of Table 2 . The second routine does instead generate some changes: we find that the zones policy has a rather large impact on the polluting behaviour of remaining state owned enterprises (the effect shifts to the remaining SOEs in areas not affected by the policy) and also among foreign investors but here rendering the previous significant positive effect of FOR on emissions insignificant. In addition there is a shift towards rendering the Public investment expenditure variable more negative and highly significant (Column 5 in Regression Table 2).

We also note that with the last specification reported in Column 5 of Table 2, population attains a rather high statistical significance in explaining emissions, which may have to do with the fact that more population dense areas also reflect larger firms with a larger employment basis. Finally does the variable Public investment expenditure also attain 
more influence in Column 5 due to the matching procedure. We will come back to this point later on, when we report the results from the final specification complete with the technology policy variable included.

Territorial policy may be part of the explanation for the reductions in emissions levels through the exercise of both formal norms (administrative measures) and informal norms (culture and imitative behaviours constraining negative externalities, as suggested by Delmas and Toffel, 2004) which are related to environmental and technology policy. It is also possible that zones attract by design firms in industries that are targeting labour-intensive and/or cost cutting activities. Prior research, however, has found that in this respect the zones have had a neutral impact (Cizkowicz et al., 2017), whereas they have not had a neutral impact on employment, suggesting that the zones are likely to foster more labour-intensive activities and this might help explain the differential behaviour we observe in the patterns of emissions by firm populations inside and outside powiats covered by the zones policy. But our calculations in Appendix 2 also suggest that this is not the whole explanation since powiats with zones are more capital intensive overall and especially when focusing on industrial capital (where total capital also includes primary sectors). Hence we cannot reject the hypothesis that the zones policy has helped to foster behavioural change which is related both with the direct and indirect impact that foreign investors have had on emissions.

As a robustness check on the results for the zones policy variable we also conducted different sample splitting exercises. ${ }^{9}$ The results we show in Table 3 are supportive of the previous results but also render additional insights. Where we cut the sample differently across columns of Table 3 to further document the impact that area heterogeneity or sample imbalance may have on the findings. In Columns 3 and 4 we split the sample into areas that at some point in time were involved in the zone policy and those areas that have never had the zone policy (many of which are rural areas). Then in the last Columns 5 and 6 we only focus on areas that have had the zone policy and split them up in two groups: after and before the policy treatment. Again, the results are particularly interesting for the variables State owned firms and Foreign owned firms: for state owned enterprises there is a very strong confirmation that the zones policy does exercise an impact on de facto polluting behaviour. Now the coefficient estimate for Foreign owned firms is consistently negative meaning that foreign investors have a negative or reducing impact on emissions levels. This is true for any sample that involves powiats involved in the policy at any point in time. Oppositely is there no or a neutral effect now of foreign investors out of the zones. Similarly, we find that within the zones, state owned enterprises do not stand out as polluters with a significant effect, whereas it is outside the zones that most of these emissions levels continue to take place.

Hence again the result support that zones are different which is related with the ownership and technological changes associated with the restructuring activities of state owned enterprises, but independently hereof also that foreign investors that locate in areas with the zones policy behave differently from investors that are not governed by the same rules and structures outside the zones. At the same times does the different sample splitting exercises also demonstrate that the difference is not due to the zones policy per se but more owing to area heterogeneity for powiats which were selected for the policy. Hence we are not able to establish any direct causality (chronologically) of the policy intervention on the polluting behaviour of foreign direct investors, but only observe that behaviour is different across areas with and without the policy. We return to a discussion of these findings in

\footnotetext{
${ }^{9}$ Even though this does not allow us to draw conclusions on the statistical significance of differences between split samples, these exercises are very helpful when it is suspected that area heterogeneity or sample imbalance could be affecting the results.
}

the final part of the paper.

\section{The role of technology policy}

In this section we use data on technology policy to investigate whether the usage of such policies have been effective in terms of curbing emissions. Until 2006 technology policy was mainly a national concern in Poland (see e.g. Brown et al., 2000), but since EU accession in 2004 and with Poland's de facto accession to the EUs structural funds in 2006 technology policy has become an area of greater concern and intervention due to the indirect higher environmental and technology standards that come with Poland's accession to the Internal Market. Hence our study provides a major opportunity to evaluate the usage of EU structural funds as a means towards reducing air pollution and therefore also a way to evaluate whether standards in trade policy such as those attached to the EU funding process and part of the Internal Market has the intended effect (see e.g. Rodrik, 2014).

One potential policy variable available in the Local Databank is the adoption of green technologies (output measure). But while there may be concerns for mild endogeneity for many of the explanatory variables used in this study, there is a stronger concern about endogeneity for this particular policy variable (see also Millimet and Roy, 2016). Reverse causality can be a major factor, since the adoption of green technology is also highly likely to be affected by (prior) levels of pollution. This concern is also embedded in the very nature of environmental regulation and enforcement, where, for example, environmental fines are channelled through public budgets towards investments that will improve the environment (see e.g. Hall, 2002). It could therefore be important to use an instrumental variables method. But also better alternative technology policy related variables are available from the Local Databank such as in particular the series on EU subsidies distributed via regional funds which has a general aim but also specifically aims to fund technology policies related with incentivising the adoption of cleaner technologies. This is arguably a very important incentive for the adoption of green technologies in the new member states (Golub, 2013). At the same time is it also likely to be independent of regional air pollution levels since EU subsidies is a general instrument used to fund many different types of public policies (see Rodriguez-Pose and Fratesi, 2004). An alternative input measure that could also serve as instrument for technology policy is the Corporate income tax which is equally available from the Local Databank over the full period of study. Instrument tests conducted initially suggest that EU subsidies are a better instrument for technology policy relative to the Corporate income tax variable. Finally, the major advantage of using both input measures is that they are available throughout the period whereas the output measure (adoption of green technology) is only available until 2008.

Hence in the final analysis we choose to focus on and report regression results where we adopt the input measures as simple covariates (rather than using an instrumental approach for an endogenous variable that is potentially tautological and also limited in time which impairs the comparability with the earlier results reported in the paper prior to the focus on technology policy).

First, the technology policy input variable $E U$ subsidies is included in the fixed effect weighted least squares specification from earlier (as reported in Column 1 in Table 4a). According to these results there is no immediate significant effect on emissions from the technology policy input variable even though the coefficient estimate has the expected sign. However, there may be multicollinearity between the Public investment expenditure variable and the $E U$ subsidies series. In the second column when omitting the former, the EU subsidies variable has a larger reducing impact on emissions levels and is now significant. This problem could also owe to co-financing whereby there is a double-counting in the sense that any EU subsidies will typically be matched in a certain proportion with a local public allocation. We therefore also defined a new variable (Pie less EU subsidies) which is the Public investment expenditure series less the EU subsidies series. Now both variables are 
Table 3

Emissions and the SEZ policy by sample selection.

\begin{tabular}{|c|c|c|c|c|c|c|}
\hline & \multicolumn{6}{|c|}{ Dependent variable: } \\
\hline & \multicolumn{6}{|c|}{ Emissions } \\
\hline & $\begin{array}{l}\text { in zones } \\
(1)\end{array}$ & $\begin{array}{l}\text { out of zones } \\
\text { (2) }\end{array}$ & $\begin{array}{c}\text { sometime zone } \\
\text { (3) }\end{array}$ & e $\quad$ never zone & $\begin{array}{l}\text { after zone } \\
\text { (5) }\end{array}$ & $\begin{array}{l}\text { before zone } \\
\text { (6) }\end{array}$ \\
\hline \multirow[t]{2}{*}{ Domestic owned firms } & 0.002 & -0.023 & -0.003 & -0.011 & 0.002 & -0.025 \\
\hline & $(0.010)$ & $(0.015)$ & $(0.020)$ & $(0.014)$ & $(0.010)$ & $(0.024)$ \\
\hline \multirow{2}{*}{ State owned firms } & -0.145 & $14.160 *$ & 5.413 & 9.009 & -0.145 & $12.504 *$ \\
\hline & $(4.379)$ & $(8.050)$ & $(4.710)$ & $(6.408)$ & $(4.379)$ & $(6.715)$ \\
\hline \multirow[t]{2}{*}{ Foreign owned firms } & $-1.656 * * *$ & 0.168 & $-1.244 * *$ & 0.041 & $-1.656 * * *$ & $-1.815^{* *}$ \\
\hline & $(0.567)$ & $(0.111)$ & $(0.499)$ & $(0.053)$ & $(0.567)$ & $(0.901)$ \\
\hline \multirow[t]{2}{*}{ Share of agriculture } & -1.480 & $9.514 * *$ & -1.367 & 9.452 & -1.480 & 6.287 \\
\hline & $(3.402)$ & $(4.489)$ & $(6.709)$ & $(5.912)$ & $(3.402)$ & $(6.311)$ \\
\hline \multirow[t]{2}{*}{ Population } & $0.005 * * *$ & $0.005^{* *}$ & $0.004 * *$ & 0.002 & $0.005^{* * *}$ & $0.010^{*}$ \\
\hline & $(0.001)$ & $(0.002)$ & $(0.002)$ & $(0.001)$ & $(0.001)$ & $(0.005)$ \\
\hline \multirow[t]{2}{*}{ Public investment expenditure } & -0.126 & 0.026 & -0.464 & -0.053 & -0.126 & 0.301 \\
\hline & $(0.219)$ & $(0.230)$ & $(0.334)$ & $(0.161)$ & $(0.219)$ & $(1.049)$ \\
\hline Observations & 2,728 & 3,319 & 4,397 & 1,643 & 2,728 & 1,669 \\
\hline R2 & 0.843 & 0.819 & 0.747 & 0.770 & 0.843 & 0.827 \\
\hline Adjusted R2 & 0.824 & 0.798 & 0.729 & 0.751 & 0.824 & 0.800 \\
\hline Residual Std. Error & $45,291.820(d f=2432)$ & $72,689.090(d f=2984)$ & $78,604.700(\mathrm{df}=$ & $4101) 49,222.580(d f=1518)$ & $45,291.820(d f=2432)$ & $89,610 \cdot 380(\mathrm{df}=1441)$ \\
\hline
\end{tabular}

Table 4a

Emissions and technology policy (proxied with EU subsidies).

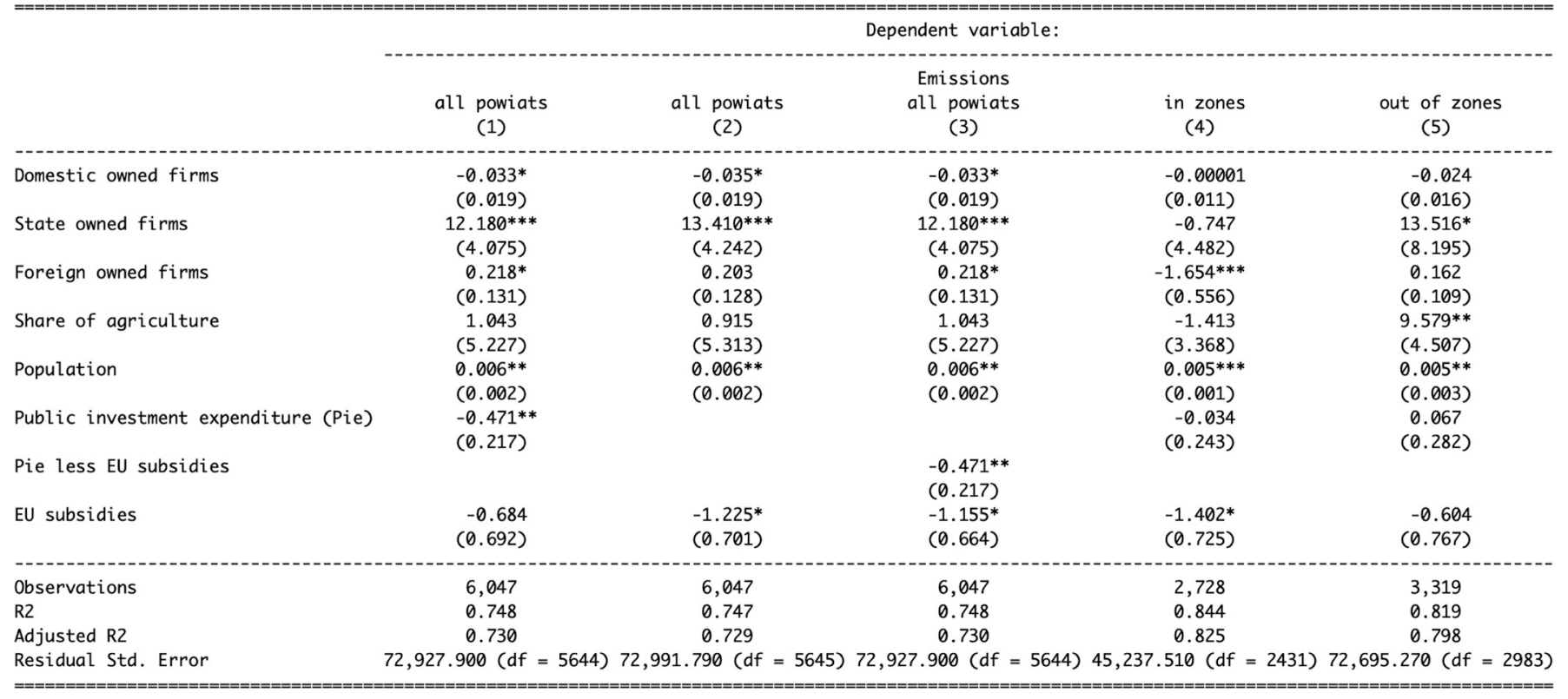

significant (Column 3 in Regression Table 4a) which confirms that most likely co-financing could be one potential cause of the multicollinearity. But the results when splitting the sample in and out of the special economic zones (Columns 4 and 5) also suggests that the collinearity is related with the zones policy. Now the significance shifts in its entity towards the EU subsidies variable (away from the Public investment expenditure variable). Following our initial study hypothesis the results show that technology policy has mainly been effective in areas that are under the zones policy. An additional 1 mio zloty spend under the structural funds within the zones policy leads to a reduction in emissions with up to $1.4 \mathrm{t}$ per year. Correctly accounting for the influences of different policies now also render the result that foreign owned firms and especially within the zones policy affected areas have a similar sized reducing effect but here measured per firm. Comparatively the structural funds are therefore spend very effectively towards reducing emissions levels even though the effect sizes are difficult to compare but we must assume that one additional foreign firm in an area involves a larger sized investment in excess of 1 mio zloty. Our preferred specification is therefore in columns 4 and 5 which best summarise the full results of the study. Remaining high emissions levels in Poland are according to these results concentrated in areas that are not under the zones policy and related either with state owned enterprises or powiats that have a very significant influence from the agricultural sector on emissions levels.

The same results are also reported with Regression Table $4 \mathrm{~b}$ for the alternative technology policy input variable (Corporate income taxes), however, we found little or no effect of this alternative policy variable, in fact the reverse, where results in particular out of the zones for the tax variable suggests that taxes are positively correlated or endogenous with emissions levels and especially in areas that are not affected by the zones policy. 
Table 4b

Emissions and technology policy (proxied with taxes).

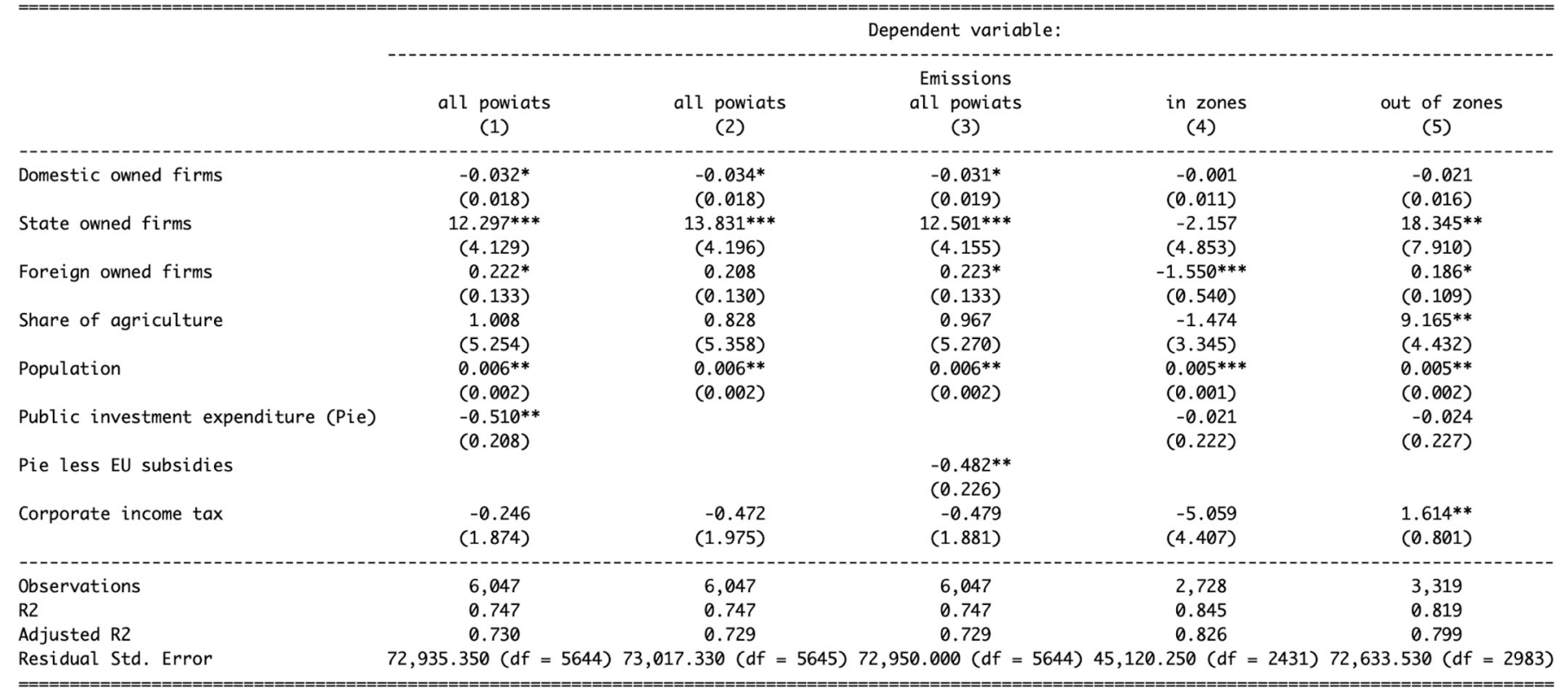

Note:

\section{Discussion and conclusion}

The objective of the study is twofold: firstly, to investigate the pollution haven hypothesis in Poland over the late transition period and EU accession (1999-2014), and secondly to identify the role of important policies influencing environmental outcomes of firm decisions, such as territorial and technology policies. Our initial results show that foreign investors on average pollute more, but still make a positive contribution to sustainability in the host country because foreign owned firms tend to be larger and therefore contribute relatively more to production, employment and exports. This is in line with prior findings in the field studied. We add to these results new findings which are important in the context of reforming economies and transition countries who may aim to cut emission levels of air pollutants as well as other similar pollutants such as water and waste. Our findings point to a positive environmental trend accompanying the transition to a marketbased system open to FDI. A fundamental determinant of PM reduction, according to our coefficient estimates, has been the implementation of technology policy, which in the later period of our time series has also received significant incentives via the EU structural funds. International technology transfer or the net contribution of foreign subsidiaries may have made a positive contribution to the sustainability balance due to the incentives associated with the SEZ territorial policy. Additional robustness checks and simple comparisons of capital intensities across areas (powiats) with and without the zones policy led to a rejection of the alternative hypothesis that the zones policy give better environmental outcomes through the impact the policy has on relative specialisation patterns and the promotion of more labour intensive, and therefore through implementation of less capital- and pollution- intensive production processes.
Our study has therefore opened up important avenues for future research on the relationship between different components of the regional development policy mix. It also shows that in many respect recent popular regional development policies such as special economic zones are far from one-dimensional and need to be evaluated more indepth.

Part of the story that would also require further investigation concerns the adoption of environmental standards in international trade negotiations (Dam and Scholtens, 2008), this would involve an analysis of how such standards, when enforced through international and/or regional trade agreements, can help to prevent the realisation of the pollution haven hypothesis. The rather positive outcome we have observed for Poland, and despite the fact that the country still has some way to go before complying with the accepted level of air pollution set by the EU and the WHO, brings the attention both to the internal drive to overcome the negative environmental spillovers of the country's industrial past and to the role played by the EU accession process and its multidimensional policy impact, which helped pave the way for a new behavioural model.

In-depth country case studies such as this present one also indicates that larger studies pooling together many different countries risk missing the important role that contextual policies and institutions have in shaping investment behaviours and the attainment of societal goals. This is unfortunate because in improving the international investment environment it is important to raise awareness of what specific policies are likely to work in specific contexts and not in others. Governments and investors are often equally responsible in generating the environmental outcomes we see because these depend on the combination of resources that are available in a system and by the institutions that shape priorities and ways of using these resources.

\section{Appendix 1. Descriptive statistics}

Table A1

Descriptive statistics 


\begin{tabular}{|c|c|c|c|c|c|c|c|}
\hline Statistic & $\mathrm{N}$ & Mean & St. Dev. & Min & Pctl(25) & Pctl(75) & Max \\
\hline Area size, ha & 6,047 & $82,731.030$ & $52,478.750$ & 1,322 & 49,423 & 116,012 & 298,696 \\
\hline Agricultural land, \% share & 6,047 & 56.864 & 16.644 & 3.755 & 46.243 & 69.903 & 115.225 \\
\hline Emissions, tonnes per year & 6,047 & 274.168 & 611.026 & 0 & 30 & 244.5 & 10,110 \\
\hline EU subsidies, mio zloty & 6,047 & 2.754 & 10.750 & 0 & 0 & 2.0 & 318 \\
\hline Domestic owned firms, no. of & 6,047 & $9,198.910$ & $18,179.830$ & 902 & 3,689 & $8,625.5$ & 351,905 \\
\hline Foreign owned firms, no. of & 6,047 & 157.942 & 984.115 & 0 & 18 & 92 & 26,907 \\
\hline State owned firms, no. of & 6,047 & 2.650 & 9.491 & 0 & 0 & 3 & 222 \\
\hline Public investment expenditure, mio zloty & 6,047 & 51.446 & 113.815 & 2.108 & 16.733 & 51.404 & $2,583.507$ \\
\hline Population, no. of & 6,047 & $101,270.900$ & $116,843.800$ & 20,778 & $55,410.5$ & 111,727 & $1,735,442$ \\
\hline Corporate income tax, mio zloty & 6,047 & 4.458 & 27.456 & -3.443 & 0.478 & 2.549 & 811.358 \\
\hline
\end{tabular}

\section{Appendix 2. Robustness check to Regression Table 1 with alternative proxy for FDI}

Based on a very short (available from 2011 onwards (until 2016) at the powiat level) and recent panel published in the Local Databank are we able to break down the estimate of gross fixed capital formation in Poland by ownership. Hence the previous variables of number of firms by ownership are replaced by two new variables: gross fixed capital formation with locally owned firms Local capital and gross fixed capital formation with foreign owned firms Foreign capital. Both variables are also measured and weighted as the investment variable e.g. in mio zloty per area. There is no possibility to distinguish between state owned and private capital within the local capital variable. We use Employment and Public investment expenditure as control variables in these estimations and estimate the model as a between effect model due to the shortness of the panel available. The results are shown with Regression Table A1.

According to Column 1 in Appendix Regression Table A1 we can now observe the net contribution of foreign capital to air pollution. Per mio zloty foreign capital invested per area, emissions of particulate matter are reduced on average with $0.125 \mathrm{t}$ of particulate matter per year. While local capital on average has a net positive effect on emission of particulate matter. When accounting for powiats with and without the zones policy the difference in the relative impact of foreign capital is much higher outside the areas with the zones policy. This could owe to heterogeneity or that the impact is lost due to the differences in specialisation patterns in and out of zones plus the fact that relatively more state owned enterprises are located and therefore also privatised (some of them with foreign capital) within the zones.

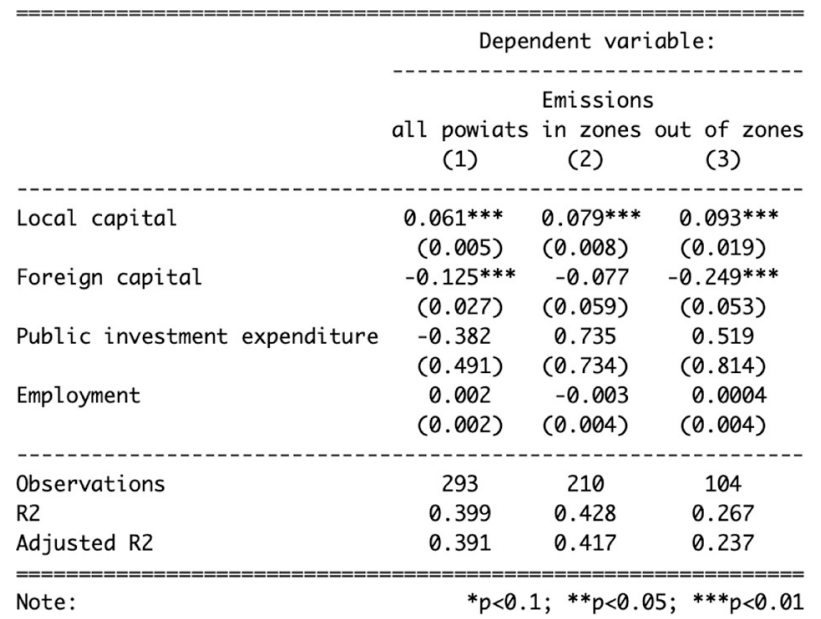

\section{Appendix Regression Table A1.}

Using the same data we can calculate the average capital intensity of powiats with and without the zones policy (but again only for a short time period bordering on the end period in our main period of study in the paper). Also note that absent data on employment by ownership we cannot make these calculations by ownership. These simple calculations of approximations to the capital-labour ratio suggest that in terms of industrial capital, powiats with the zones policy are generally more capital intensive but less so when measured on total capital intensity (where the latter includes capital in primary sectors and agriculture). 


\begin{tabular}{|c|c|c|}
\hline & \multicolumn{2}{|c|}{ Dependent variable: } \\
\hline & $\begin{array}{l}\text { KL ratio } \\
\text { Industrial capital only Tota } \\
\text { (1) }\end{array}$ & $\begin{array}{l}\mathrm{KL} \text { ratio } \\
\text { capital aparatus } \\
\text { (2) }\end{array}$ \\
\hline SEZ & $\begin{array}{r}0.028 * * * \\
(0.010)\end{array}$ & $\begin{array}{l}0.023 * * \\
(0.010)\end{array}$ \\
\hline Constant & $\begin{array}{r}0.079 * * * \\
(0.008)\end{array}$ & $\begin{array}{l}0.123 * * * \\
(0.008)\end{array}$ \\
\hline Observations & 293 & 293 \\
\hline $\mathrm{R} 2$ & 0.027 & 0.017 \\
\hline Adjusted R2 & 0.024 & 0.013 \\
\hline
\end{tabular}

Appendix Regression Table A2.

Appendix 3. Summary output from balancing statistics

Table A2 summarises the percent balance improvement for the two matches. Additional output from R (not shown) demonstrates that these aggregates hide over a significant amount of year-to-year variation in the same statistics. The differential performance over time owes to the dynamic character of the policy intervention and its reach. In the beginning (in 1999) there are very few treated areas while at the end of the period of study (in 2014) there are more treated areas than control areas left. Neither match performs particularly well according to these statistics and also the statistics are quite sensitive to the setting of seed in $\mathrm{R}$ towards starting the matching routine.

Table A2

Percent balance improvement from using Mahalanobis distance matching.

\begin{tabular}{lcc}
\hline & Match 1 & \\
\hline & & \\
Domestic owned firms & -14.56 & -64.98 \\
State owned firms & -436.53 & -33.86 \\
Foreign owned firms & 9.58 & 39.52 \\
Share of agriculture & -33.39 & -66.16 \\
Population & -24.10 & -22.85 \\
Public investment expenditure & 77.99 & -6686.07 \\
Treated/control & Varies by year (unbalanced panel) & $99 / 99$ (balanced panel) \\
\hline
\end{tabular}

\section{References}

Adekoya, Remi, 2016. Confusing Signals from Warsaw. Central European Financial Observer.eu. https://financialobserver.eu/poland/confusing-signals-from-warsaw/, Accessed date: 21 February 2016.

Akbostanci, E., Tunc, G.I., Turut-Asik, S.E.R.A.P., 2007. Pollution haven hypothesis and the role of dirty industries in Turkey's exports. Environ. Dev. Econ. 12 (2), 297-322.

Andersson, M., 2012. Change and Continuity in Poland's Environmental Policy. vol. 20 Springer Science \& Business Media, Dordrecht.

Ang, J.B., 2009. CO 2 emissions, research and technology transfer in China. Ecol. Econ. 68 (10), 2658-2665.

Bachtler, J., Turok, I. (Eds.), 2013. The Coherence of EU Regional Policy: Contrasting Perspectives on the Structural Funds. Routledge, London.

Bommer, R., 1999. Environmental policy and industrial competitiveness: the pollution haven hypothesis reconsidered. Rev. Int. Econ. 7 (2), 342-355.

Brown, H.S., Angel, D.P., Derr, P.G., 2000. Effective Environmental Regulation: Learning From Poland's Experience. Greenwood Publishing Group, Westport, CT.

Cameron, A.C., Gelbach, J.B., Miller, D.L., 2011. Robust inference with multiway clustering. J. Bus. Econ. Stat. 29 (2), 238-249.

Candau, F., Dienesch, E., 2017. Pollution haven and corruption paradise. J. Environ. Econ. Manag. 85, 171-192.

Cave, L.A., Blomquist, G.C., 2008. Environmental policy in the European Union: fostering the development of pollution havens? Ecol. Econ. 65 (2), 253-261.

Ciezlik, A., Ryan, M., 2005. Location determinants of Japanese multinationals in Poland: do special economic zones really matter for investment decisions? J. Econ. Integr. 475-496.

Cizkowicz, P., Cizkowicz-Pekala, M., Pekala, P., Rzonca, A., 2017. The effects of special economic zones on employment and investment: a spatial panel modeling perspective. J. Econ. Geogr. 17 (3), 571-605.

Cole, M.A., 2004. Trade, the pollution haven hypothesis and the environmental Kuznets curve: examining the linkages. Ecol. Econ. 48 (1), 71-81.

Cole, M.A., Elliott, R.J., 2003. Determining the trade-environment composition effect: the role of capital, labor and environmental regulations. J. Environ. Econ. Manag. 46 (3), 363-383.

Cole, M.A., Elliott, R.J., Zhang, J., 2011. Growth, foreign direct investment, and the environment: evidence from Chinese cities. J. Reg. Sci. 51 (1), 121-138.

Cole, M.A., Elliott, R.J., Zhang, L., 2017. Foreign direct investment and the environment. Annu. Rev. Environ. Resour. 42, 465-487.

Costantini, V., Mazzanti, M., 2012. On the green and innovative side of trade competitiveness? The impact of environmental policies and innovation on EU exports. Res. Policy 41 (1), 132-153.

Dam, L., Scholtens, B., 2008. Environmental regulation and MNEs location: does CSR matter? Ecol. Econ. 67 (1), 55-65.

Dam, L., Scholtens, B., 2012. The curse of the haven: the impact of multinational enterprise on environmental regulation. Ecol. Econ. 78, 148-156.

De Lucia, C., 2010. Environmental Policies for Air Pollution and Climate Change in the New Europe. Routledge, London.

Delmas, M., Toffel, M.W., 2004. Stakeholders and environmental management practices: an institutional framework. Bus. Strateg. Environ. 13 (4), 209-222.

Domanski, B., 2003. Industrial change and foreign direct investment in the postsocialist economy: the case of Poland. Eur. Urban Reg. Stud. 10 (2), 99-118.

Dorożyński, T., Świerkocki, J., Urbaniak, W., 2017. FDI inflow to special economic zones in Poland: regional approach. J. Manag. Financ. Sci. 10 (27), 87-103.

Edmondson, D.L., Kern, F., Rogge, K.S., 2018. The co-evolution of policy mixes and sociotechnical systems: towards a conceptual framework of policy mix feedback in sustainability transitions. Res. Policy (in press).

EEA, 2016. Air Quality in Europe - 2016 Report. European Environment Agency, Luxembourg.

Elliott, R.J., Shimamoto, K., 2008. Are ASEAN countries havens for Japanese pollutionintensive industry? World Econ. 31 (2), 236-254.

Erdogan, A.M., 2014. Foreign direct investment and environmental regulations: a survey. J. Econ. Surv. 28 (5), 943-955.

Eskeland, G.S., Harrison, A.E., 2003. Moving to greener pastures? Multinationals and the pollution haven hypothesis. J. Dev. Econ. 70 (1), 1-23.

Flanagan, K., Uyarra, E., Laranja, M., 2011. Reconceptualising the policy mix for innovation. Res. Policy 40 (5), 702-713.

Geels, F.W., 2002. Technological transitions as evolutionary reconfiguration processes: a multi-level perspective and a case-study. Res. Policy 31 (8-9), 1257-1274.

Geels, F.W., 2004. From sectoral systems of innovation to socio-technical systems: insights about dynamics and change from sociology and institutional theory. Res. Policy 33 (6-7), 897-920. 
Golub, J. (Ed.), 2013. New Instruments for Environmental Policy in the EU. Routledge, London.

GUS. (2016). Environment 2016. Glowny Urzad Statystyczny. Warsaw. http://stat.gov. $\mathrm{pl} / \mathrm{en} /$ topics/environment-energy/environment/environment-2016,1,8.html.

GUS, 2017. Green Lungs of Poland in 2015. Glowny Urzad Statystyczny, Bialystok.

Gwosdz, K., Jarczewski, W., Huculak, M., Wiederman, K., 2008. Polish special economic zones: idea versus practice. Environ. Plan. C Gov. Policy 26 (4), 824-840.

Hall, B.H., 2002. The financing of research and development. Oxf. Rev. Econ. Policy 18 (1), 35-51.

He, J., 2006. Pollution haven hypothesis and environmental impacts of foreign direct investment: the case of industrial emission of sulfur dioxide ( $\mathrm{SO}$ 2) in Chinese provinces. Ecol. Econ. 60 (1), 228-245.

Hering, L., Poncet, S., 2014. Environmental policy and exports: evidence from Chinese cities. J. Environ. Econ. Manag. 68 (2), 296-318.

Hlavac, Marek, 2015. Stargazer: Well-formatted Regression and Summary Statistics Tables. R package version 5.2.. http://CRAN.R-project.org/package $=$ stargazer.

Jaffe, A.B., Peterson, S.R., Portney, P.R., Stavins, R.N., 1995. Environmental regulation and the competitiveness of US manufacturing: what does the evidence tell us? J. Econ. Lit. 33 (1), 132-163.

Jensen, C., 2002. Foreign direct investment, industrial restructuring and the upgrading of Polish exports. Appl. Econ. 34 (2), 207-217.

Jensen, C., 2007. Institutional contexts and FDI trends in European emerging economies. In: Meyer, K.E., Estrin, S. (Eds.), Acquisition Strategies in European Emerging Markets. Palgrave Macmillan, Basingstoke.

Jensen, C., 2018. The employment impact of Poland's special economic zones policy. Reg. Stud. 52 (7), 877-889.

Kellenberg, D.K., 2009. An empirical investigation of the pollution haven effect with strategic environment and trade policy. J. Int. Econ. 78 (2), 242-255.

Kheder, S.B., Zugravu, N., 2012. Environmental regulation and French firms location abroad: an economic geography model in an international comparative study. Ecol. Econ. 77, 48-61.

Krzyzanowski, M., Cohen, A., 2008. Update of WHO air quality guidelines. Air Qual. Atmos. Health 1 (1), 7-13.

Lanjouw, J.O., Mody, A., 1996. Innovation and the international diffusion of environmentally responsive technology. Res. Policy 25 (4), 549-571.

Leiter, A.M., Parolini, A., Winner, H., 2011. Environmental regulation and investment: evidence from European industry data. Ecol. Econ. 70 (4), 759-770.

Leoncini, R., Montresor, S., Rentocchini, F., 2016. CO 2-reducing innovations and outsourcing: evidence from photovoltaics and green construction in North-East Italy. Res. Policy 45 (8), 1649-1659.

Letchumanan, R., Kodama, F., 2000. Reconciling the conflict between the pollution- haven' hypothesis and an emerging trajectory of international technology transfer. Res. Policy 29 (1), 59-79.

Manderson, E., Kneller, R., 2012. Environmental regulations and innovation activity in UK manufacturing industries. Resour. Energy Econ. 34 (2), 211-235.

Millimet, D.L., Roy, J., 2016. Empirical tests of the pollution haven hypothesis when environmental regulation is endogenous. J. Appl. Econ. 31 (4), 652-677.

Mulatu, A., 2017. The structure of UK outbound FDI and environmental regulation. Environ. Resour. Econ. 68 (1), 65-96.

Naughton, H.T., 2014. To shut down or to shift: multinationals and environmental regulation. Ecol. Econ. 102, 113-117.

OECD, 2012. Environmental Performance Reviews. Poland. Organisation for Economic Co-operation and Development, Paris.

OECD, 2015. Environmental Performance Reviews. Poland. Organisation for Economic Co-operation and Development, Paris.

PAGE, 2017. The Green Economy Progress Measurement Framework. United Nations Environment Programme, Paris.

Panhans, M., Lavric, L., Hanley, N., 2016. The effects of electricity costs on firm re-location decisions: insights for the pollution havens hypothesis? Environ. Resour. Econ. $1-22$.

Peng, M.W., 2001. How entrepreneurs create wealth in transition economies. Acad. Manag. Exec. 15 (1), 95-108.

Poelhekke, S., Van der Ploeg, F., 2015. Green havens and pollution havens. World Econ. 38 (7), 1159-1178.

Rezza, A.A., 2013. FDI and pollution havens: evidence from the Norwegian manufacturing sector. Ecol. Econ. 90, 140-149.

Rodriguez-Pose, A., Fratesi, U., 2004. Between development and social policies: the impact of European Structural Funds in Objective 1 regions. Reg. Stud. 38 (1), 97-113.

Rodrik, D., 2014. Green industrial policy. Oxf. Rev. Econ. Policy 30 (3), 469-491.

Rogge, K.S., Reichardt, K., 2016. Policy mixes for sustainability transitions: an extended concept and framework for analysis. Res. Policy 45 (8), 1620-1635.

Stuart, E.A., King, G., Imai, K., Ho, D.E., 2011. MatchIt: nonparametric preprocessing for parametric causal inference. J. Stat. Softw. 42 (8).

Tang, D., Li, L., Yang, Y., 2016. Spatial econometric model analysis of foreign direct investment and haze pollution in China. Pol. J. Environ. Stud. 25 (1).

Taylor, M.S., 2004. Unbundling the pollution haven hypothesis. Adv. Econ. Anal. Policy $3(2)$.

Wagner, U.J., Timmins, C.D., 2009. Agglomeration effects in foreign direct investment and the pollution haven hypothesis. Environ. Resour. Econ. 43 (2), 231-256.

WHO \& UNAIDS, 2006. Air Quality Guidelines: Global Update 2005. World Health Organization, Geneva. 